\title{
AZOLLA ENHANCES ELECTRICITY GENERATION OF PADDY MICROBIAL FUEL CELL
}

\author{
Roshan Regmi and Rachnarin Nitisoravut* \\ School of Bio-Chemical Engineering and Technology, \\ Sirindhorn International Institute of Technology, Thammasat University \\ Pathum Thani, Thailand, Tel: +66-2-986-9009 ext. 2304, e-mail: snitisor@ siit.tu.ac.th
}

Received Date: January 3, 2018; Revised Date: January 16, 2020; Acceptance Date: January 20, 2020

\begin{abstract}
Generation of electricity from plant rhizodeposition with an aid of soil bacteria has gained popularity recently as a source of clean and green energy. Power generation from such biosystems is lower than theoretically achieved value due to many constraints. Supplementing the rhizodeposition with external substrates or in situ complementary mechanism can help to enhance the current generation. Therefore, this study aims to improve current from paddy plants with an amendment of Azolla which is hypothesized to augment the bioelectricity production via two mechanisms. These include an addition of organic matters in the system and nitrogen fixation from Azolla which plays a positive role in biomass growth, thereby increasing current. Single chamber sediment PMFCs were built in a facile way, employing commercially available glass chambers with carbon cloth for electrodes, and paddy soil as substrates and inoculum. To have better insight about the system performance, numerous parameters were monitored including daily power output recordings, nature of electric signals, polarization technique, growth nature of the plant, and change in soil physiochemical characteristics. The results revealed that after a week of transplanting of paddy seedlings, the daily current density increased almost twice as compared to the unplanted system. The maximum power in planted reactors was greater by $84 \%$ as depicted by power curve. In addition, amended planted reactors with Azolla enhanced the current generation by almost thrice than only planted reactors without amendment, while planted reactors produced current twice than that of from sediments only. Clear circadian oscillation was observed in power output from closed circuit while there is no such demarcation in open circuit voltage during the start-up period.
\end{abstract}

Keywords: Biosystem, PMFC, Power generation, Rhizodeposition

\section{Introduction}

Excessive usage of fossil fuels tends to incite many problems, the major one of which is climate change. To mitigate the use of the carbon-emitting source of energy, many kinds of alternative and sustainable energy technologies have been researched and tested. Lately, the proposed technology called microbial fuel cell (MFC) has engrossed a tremendous attention of researchers and stakeholders. MFCs convert chemical energy stored in the organic matters to electricity whilst, generating electricity through a bacterial metabolism with no environmental footprints [1]. A typical MFC comprises of anode, cathode and proton exchange membrane. The anode is where oxidation of organic matters by microbes take place with the release of electrons and protons. Electrons are carried away by the current collector (wire) and protons are transferred to the cathode via a proton exchange membrane. At the cathode, the reduction reaction occurs, 
where electrons, protons and oxygen combined to form water. Favorable condition at the anode is a strictly anaerobic environment while the aerobic condition is necessary at the cathode [2].

The principle for generating electricity has been applied in different configurations and methods. Plant microbial fuel cell (PMFC) is a progeny of MFC where anodic organic matter is supplied by the plant's rhizodeposition [3]. Different types of plants like marshy grasses, hydrophytes, and paddy have been used in studies for green electricity generation and wastewater treatment [4]. Paddy is one of the suitable plants which can be operated as a paddy microbial fuel cell (PMFC) system. Waterlogged condition around rhizosphere to favour anaerobic condition for the oxidation process and overlying water supporting aerobic condition for oxygen reduction attract researchers to work in PMFC [5]. Power output from PMFC is dependent on various factors and stable current generation is always challenging. Moreover, in a present scenario, the working voltage generated is still not enough for useful work.

Attempts were made earlier to increase the power generation from PMFC using different sources of organic matters [6]. For long-term application of PMFC, it is important to get insight on power generation under various conditions. This study investigated the electricity generation under three different conditions. At first, electric signals from only unplanted sediment MFC were recorded. Secondly, the comparison was done between planted PMFC and unplanted sediment MFC. Finally, an attempt was made to evaluate the effect of Azolla amendment on electricity production. The use of Azolla in PMFC is motivated from the traditional use of it as a biofertilizer. In PMFC, mutualism of Azolla could enhance the power generation by extra organic matters and other allied factors yet to be explained. Multiple MFC were stacked to maximize the voltage to demonstrate the possible application of the proposed system.

\section{Materials and Methods}

\section{Microcosm Set Up}

Unplanted sediment MFCs were constructed with soil collected from paddy research field of Thammasat University, Thailand from upper layer ranging $0-10 \mathrm{~cm}$. Soil suspension was filtered through a sieve to remove any coarse debris. Glass containers $\left(20 \times 15 \times 10 \mathrm{~cm}^{3}\right)$ were used as a material unit for each reactor. Small pebbles were placed up to $2 \mathrm{~cm}$ at the bottom for facilitating the anolyte collection and increasing the circulation of water in sediment. Untreated carbon cloth measuring $150 \mathrm{~cm}^{2}$ was fixed with a silicone sealant just above pebbles that act as anode and cathode measuring the same size as an anode was located between soil-water interfaces. The plastic tube was placed vertically to collect sediment for analysis as well as for feeding to the anode chamber. Thin Titanium wire passed through the plastic tube was used as a current collector for both electrodes. Azolla pinnata was collected from the open pond of Pathum Thani province, Thailand was used in this study. Azolla was mixed with the soil as a soil amendment and placed in the cathode in treated reactors. Paddy seedlings of 3-4 weeks were transplanted to planted reactors. The schematic configuration of the system is shown in Figure 1.

\section{PMFC Operation}

The microcosms were run for 90 days. Total of six reactors was operated. For the first month, the reactors were run only with unplanted sediment; first 17 days in open circuit condition (OCV) and later 13 days in the closed circuit to record electricity generation. After that six reactors were run into the duplicate. Three reactors identical of each treatment were run parallel 
in open circuit condition. Afterwards, for 35 days, electricity generation from planted and unplanted reactors was recorded. The last 25 days were accompanied with Azolla amendment in treated reactors followed by 5 days of stacking of all reactors together. Table 1 shows the experimental conditions during the entire period of study.

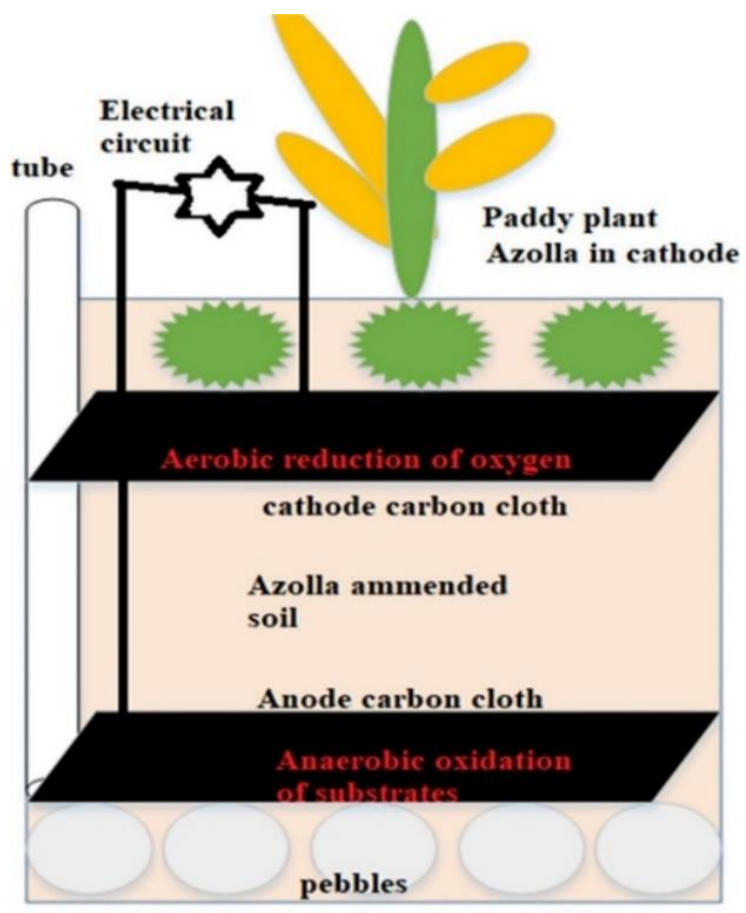

Figure 1. Schematic of paddy-Azolla plant microbial fuel cell

Table 1. Experimental Set-up and Operating Conditions

Days of Operation

0-17 Open circuit condition from unplanted sediments

17-30 Closed circuit condition from unplanted sediments

30-65 Closed circuit condition from unplanted sediment, and planted PMFC

65-90 Closed circuit condition from unplanted sediment, planted sediment, Azolla amended planted

\section{Objectives}

To acclimatize microbes

To investigate electric output behavior from sediment

To compare planted reactors with unplanted reactors

To compare the efficacy of Azolla amended reactors with planted and unplanted reactors

\section{Analyses}

Electrical measurements were done by multimeter offline and data acquisition online (every half an hour), i.e. 48 data points for each day for each reactor. Soil physiochemical property was performed in according to the standard method. The growth of paddy biomass was monitored by measuring the height of plants and counting panicle numbers. Fuel cell behavior of a system 
was characterized by polarization curves using a resistor box comprising variable resistors. The maximum point in the power curve was used to compare the system performance in terms of electricity generation. Daily power generation was also considered to differentiate the bestperforming reactors with others. The fixed resistor of $100 \mathrm{Ohms}$ was used in closed circuit condition to calculate the voltage and current, thereafter power. The obtained voltage from the measuring device was converted to current using Ohms Law $(I=V / R)$. Power was obtained by multiplying voltage with current.

\section{Results and Discussion}

\section{Electricity Generation from Sediments}

All six reactors were operated without any external resistor for 17 days for better acclimatization of electrochemically active bacteria in the system. After 17 days, all the reactors were connected externally with $100 \mathrm{Ohms}$. All the reactors showed an inclining trend in OCV from day 1 to day 17. Increment trend in OCV with time can be attributed to the well developed anaerobic region and enrichment of microbial film around the anodic region [7].

Figure 2 illustrates an average OCV from six reactors maximum value of which was $630 \mathrm{mV}$. While operating as an open circuit, there was no clear day and night demarcation in OCV generation. However, after connecting an external resistor after day 17, a clear crest and trough were observed in the current generation (Figure 3). In closed circuit condition, electrons are continuously received in anode via electrons shuttles from bacterial metabolisms which resist an external hindrance (resistor) imposed and reached to a cathode, producing an electric signal. Closed circuit reflects most thoroughly the microbial activity and nature of substrates/ fuels supplied, while OCV was mostly attributed to configuration design and physical in nature, in this case, true bio-electrochemical characteristics of a system might not be represented.

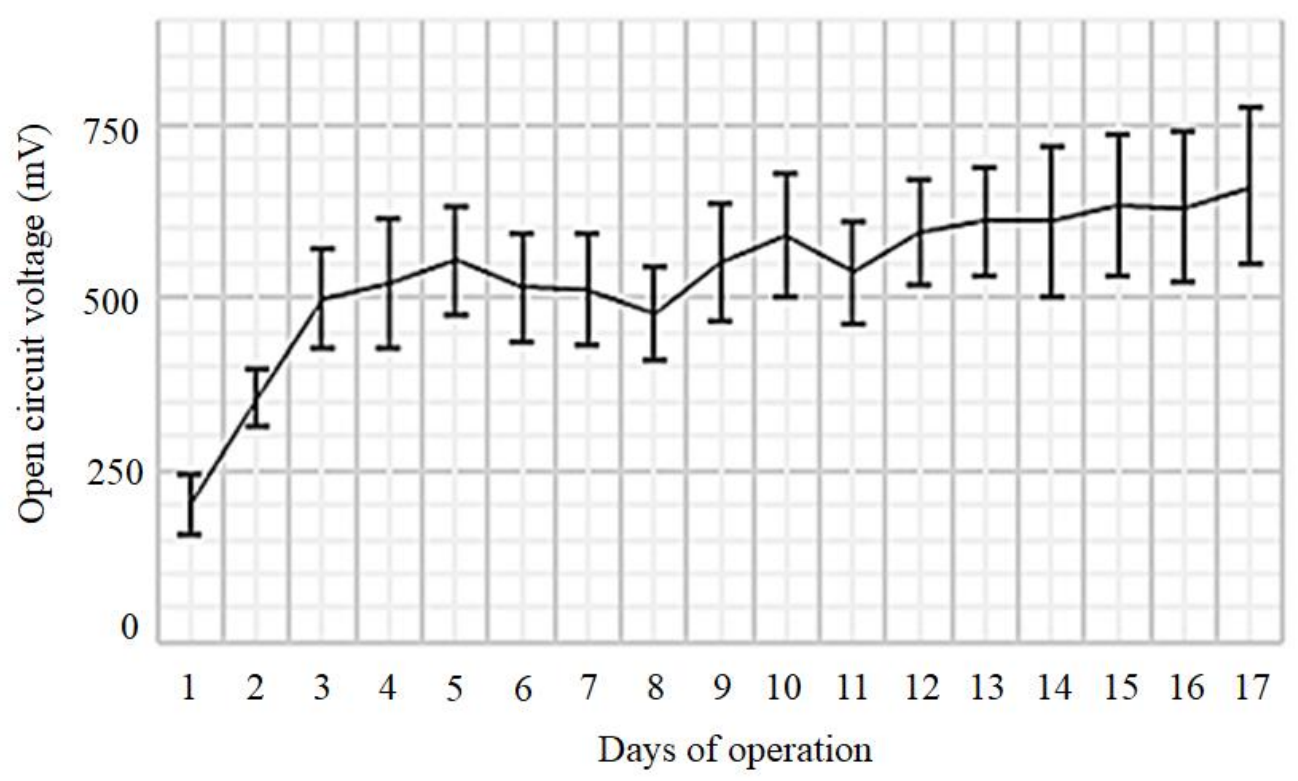

Figure 2. Open circuit voltage from unplanted sediments (Error bar indicates the standard deviation of six reactors) 


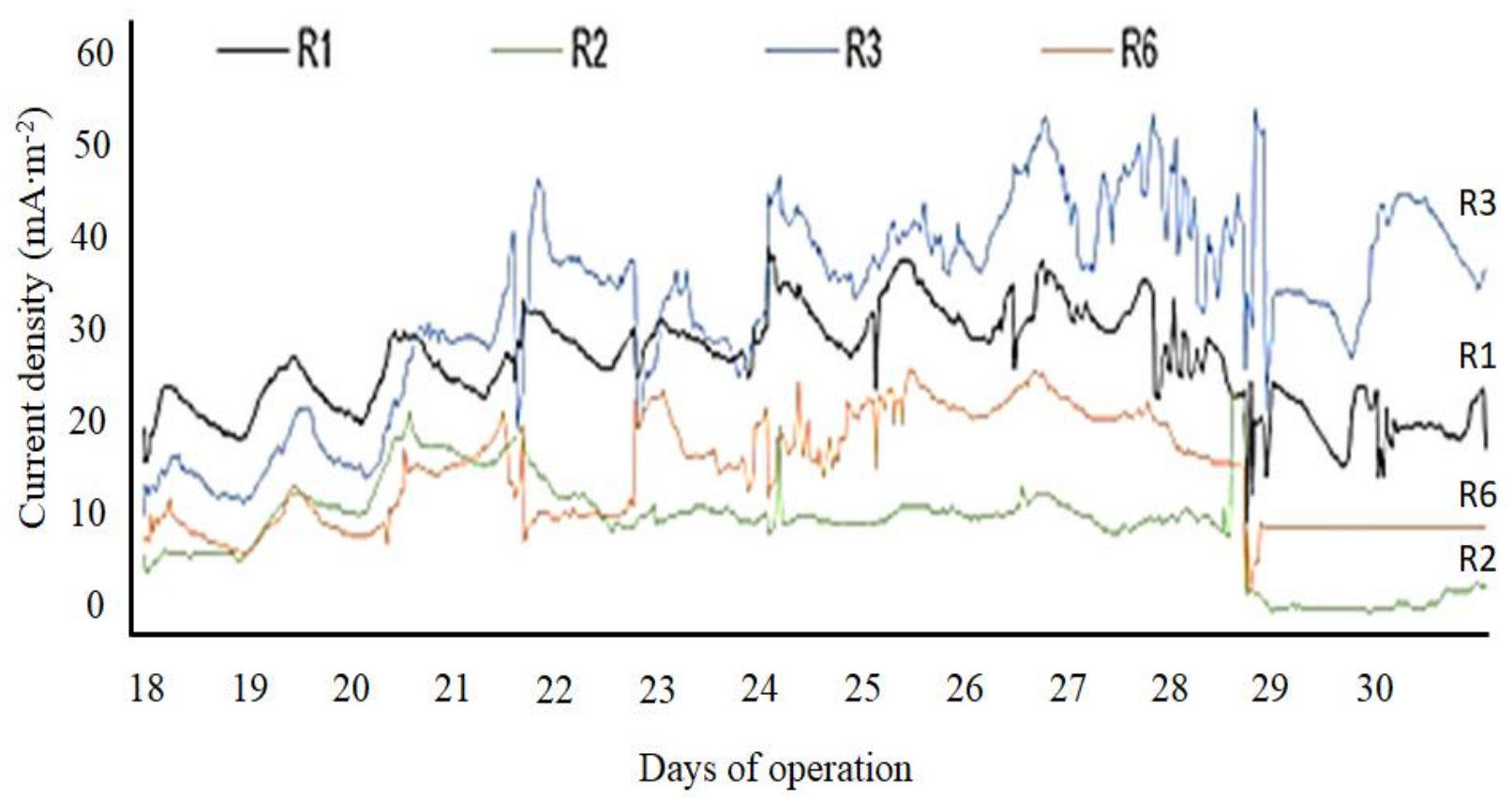

Figure 3. Diurnal fluctuation in closed circuit current from unplanted sediments for 13 days of operation

Running reactors in OCV condition might have two major significances. Firstly, the fate of reactor performance in generating the maximum power is determined by OCV it would generate. Secondly, sufficient time for bacteria in open circuit condition should be provided for their acclimatization in an electrode and formation of biofilm. Day and night fluctuation in the closed circuit is attributed to the effect of light intensity in photos ynthetic bacteria. Another reason for enhanced performances in a day-time might be due to the effect of temperature. Bacterial metabolism might be favoured with optimum temperature (28-35 degree Celsius) leading towards the peak in current generations.

\section{Effect on Current Generation by Plantation}

After one month of operation with sediment only, those reactors that performed better in the closed- circuit were used as the control with no plantation of paddy and lower performed reactors were planted with 22 days old paddy seedlings (2-3 in numbers). After a week of transplanting paddy, the planted reactors significantly showed an increment in the current generation which was almost thrice than that of unplanted during day-time (Figure 4). However, at night the extent of the current generation is lower than that of day-time. During daytime, photosynthesis in presence of sunlight leads increased organic matters in form of carbohydrates translocate to the root zone. Thus, bacteria can oxidize the higher amounts of fuel $[8,9]$, consequently leading towards to an augmented performance. Similar phenomena have been observed in the previous study while studying Ipomoea aquatic operated MFC [10]. In that study there was no fluctuation in the unplanted sediment microbial fuel cell, however, in our study, there is some fluctuation in sediment microbial fuel cell in terms of diurnal current generation. Nevertheless, the extent of the current generation and circadian oscillation is more pronounced in planted reactors. 


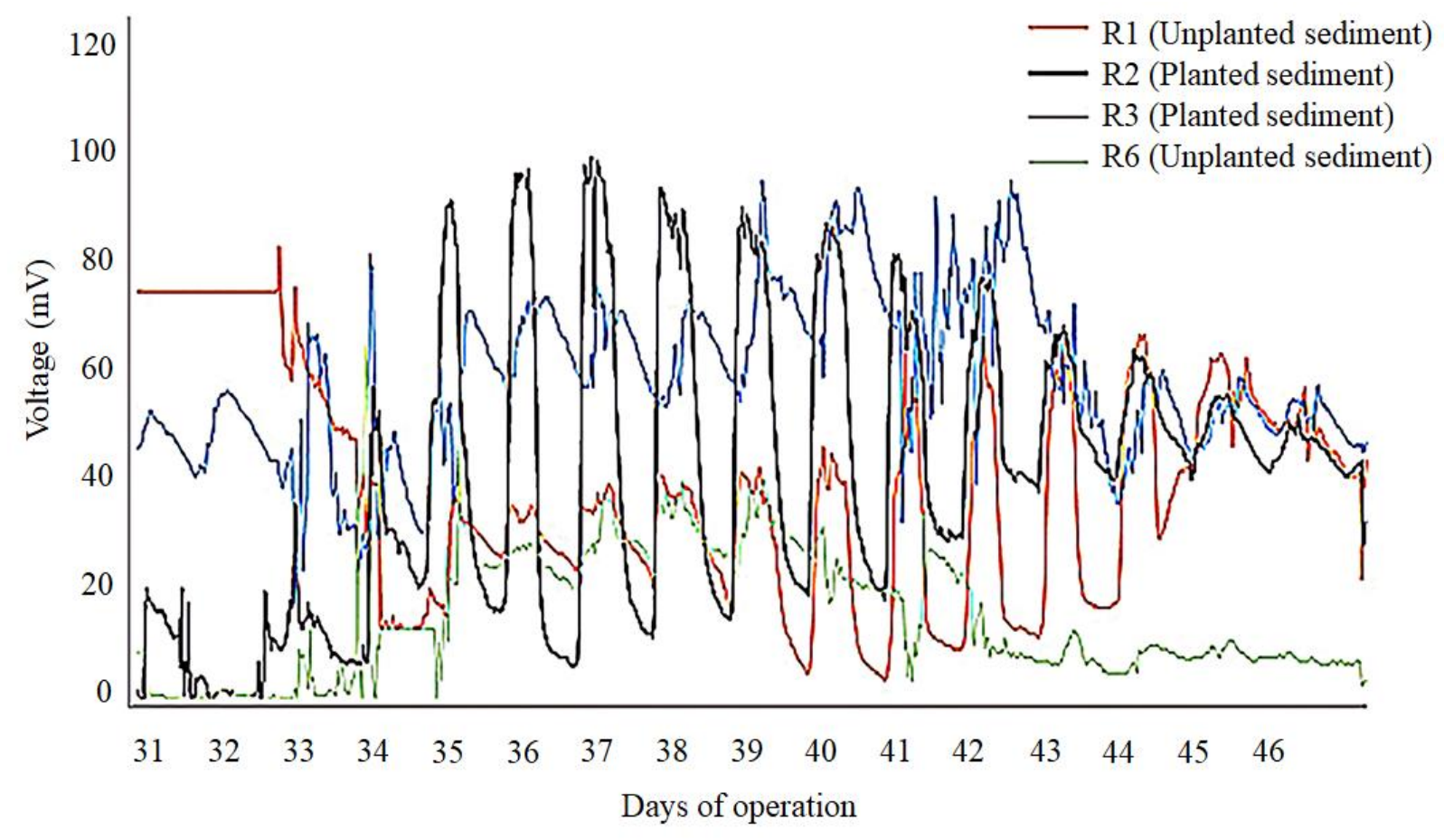

Figure 4. Voltage generation across $100 \mathrm{Ohms}$ in planted and unplanted reactors

As shown in the figure, planted reactors $\mathrm{R} 2$ and $\mathrm{R} 3$ produced higher voltage than unplanted reactors (R1 and R6). Unplanted sediment reactor (R1) exhibited an increasing trend after 40 days of operation. It might be due to an algal activity that is visible in this reactor. Algae can act as biocathode and enhances the bioelectricity generation by promoting the reduction of oxygen [11]. Although at the daytime, the trend of planted reactors was significantly higher than the unplanted reactors, there was no significant increment on an average current for the period of 35 days while averaging 48 data points (including day and night). After 65 days of operation, polarization curves were constructed in clear sunny day for planted and unplanted reactors before inoculating of Azolla. The maximum power density as depicted by power curve was $22 \mathrm{mw} / \mathrm{m}^{2}$ for the planted reactor (R2), however unplanted reactor (R1) only yielded $3.3 \mathrm{~mW} / \mathrm{m}^{2}$ (Figure 5). Similar power density in the paddy microbial fuel cell was reported in the earlier study [6]. As seen in the polarization curve, voltage decreased sharply on the higher current density suggesting mass transfer limitations, which might be due to soil particles itself hindering the transfer of anolyte $[1$, 12].

\section{Effect on Current Generation by Azolla Amendment}

A handful of Azolla pinnata was added to the soil around the cathode region in two reactors. Besides, soil amendment, the same amount was floated in the water around the cathode region. When Azolla covered all the cathode region, it might block oxygen to reach to the cathode. An attempt was made to facilitate aerobic region in the cathode chamber by providing enough space between Azolla so that atmospheric oxygen can reach enough to cathode region. Moreover, periodic blowing of the cathode was done with a tube. In this 
stage, reactors were categorized into three groups, two reactors each for unplanted (NA + $\mathrm{NP})$, planted $(\mathrm{NA}+\mathrm{P})$ and planted with Azolla $(\mathrm{A}+\mathrm{P})$. The daily current generation was recorded for 25 days. Forty-eight data sets were made the average for a day and daily values were again averaged representing the whole stage. The current was normalized to an effective anode area.

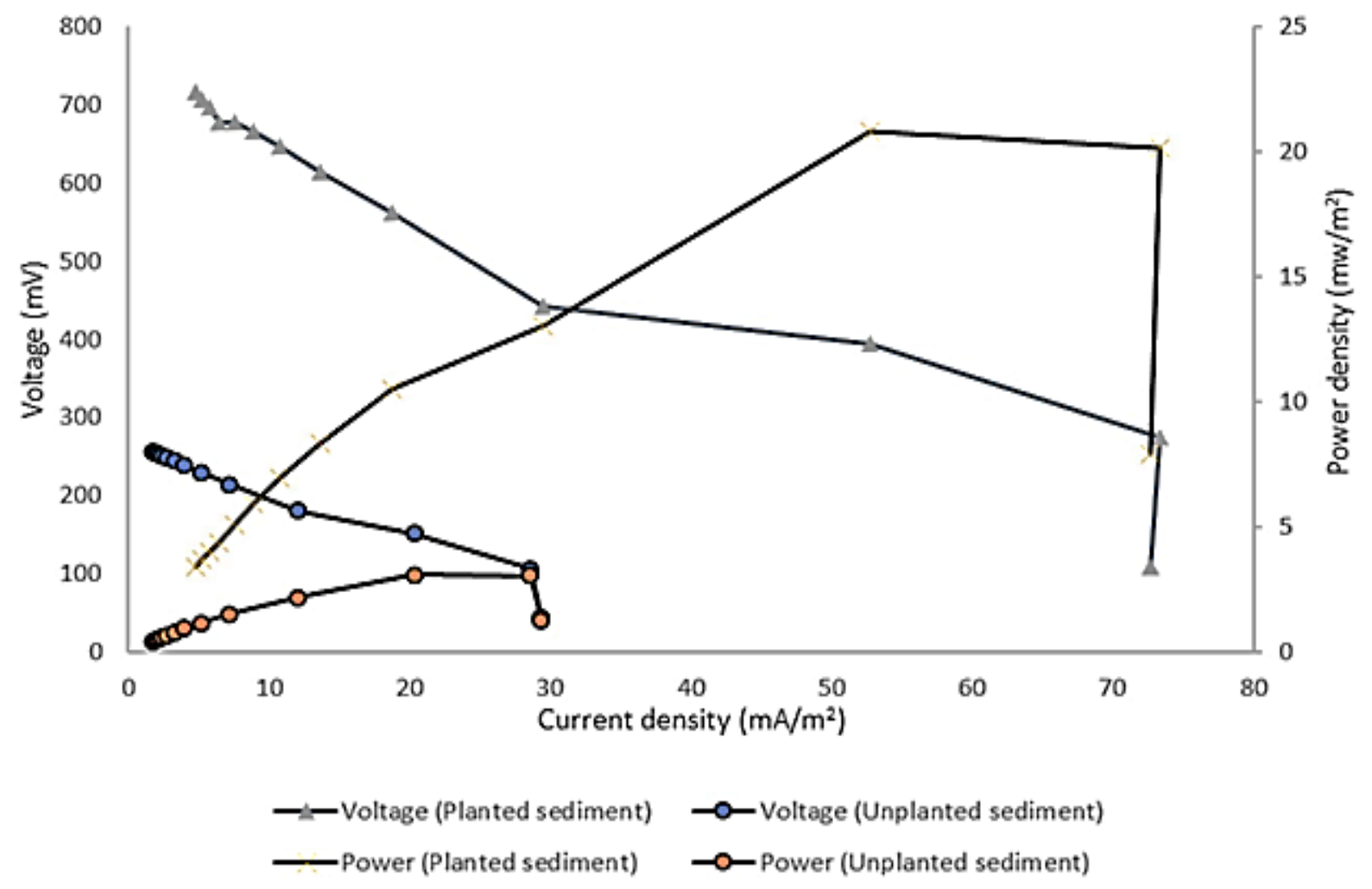

Figure 5. Polarization curve for planted and unplanted reactors

With the excessive growth of the plant and Azolla amendment, all planted reactors performed better than unplanted reactors in the third phase. The results revealed that Azolla amended planted reactors produced the current density of $205 \mathrm{~mA} / \mathrm{m}^{2}$ and $190 \mathrm{~mA} / \mathrm{m}^{2}$ in duplicate reactors against planted reactors without amendment, i.e. $66 \mathrm{~mA} / \mathrm{m}^{2}$ and 109 $\mathrm{mA} / \mathrm{m}^{2}$. While unplanted sediment reactors only gave an average $32 \mathrm{~mA} / \mathrm{m}^{2}$ and $31 \mathrm{~mA} / \mathrm{m}^{2}$ (Figure 6). Improvement of system performance with Paddy-Azolla biosystem might be attributed to an increase of organic matters via a soil amendment. In addition to this, floating Azolla can continuously supply nitrogen via nitrogen fixation to the paddy thereby enhancing their growth which was evident from the nature of growth in amended reactors and without amended reactors [13]. Interestingly, overlying water in the cathodic region with Azolla was clear in comparison to other reactors. It might be because of adsorption and uptake of nutrients from cathodic water [14], which otherwise can decline the system performance. The major challenge among these best-performing reactors was higher fluctuation in the power generation. Further studies should be focused on improving the power generation with such amendment with low fluctuation in the electric signal. Stable power is essential for their pragmatic applications. 


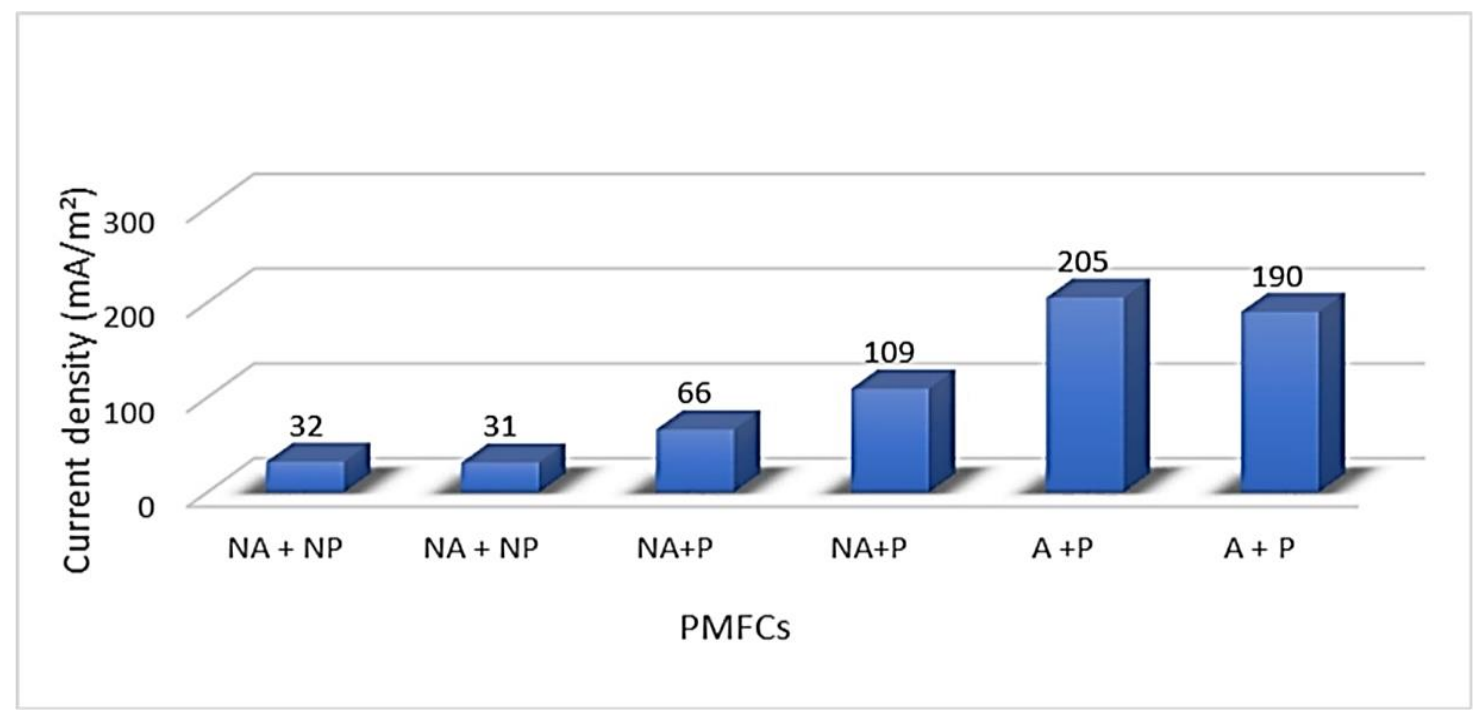

Figure 6. Comparison of unplanted sediment $(\mathrm{NA}+\mathrm{NP})$, planted sediment $(\mathrm{NA}+\mathrm{P})$ and planted with Azolla amended $(\mathrm{A}+\mathrm{P})$ reactors

\section{Conclusions and Outlook}

This study investigated the first time the feasibility of using Azolla as a substrate in paddy-Azolla biosystems microbial fuel cell. Current generation from only unplanted sediments planted and Azolla-planted reactors were analyzed. Planted reactors enhanced the electric generation significantly during day-time however at night, there was no remarkable difference in planted and unplanted reactors. Closed circuit current exhibited the clear crest and trough, but no such demarcation was seen in open circuit condition. Azolla amendment improved the current generation by almost twice than only planted reactors and more than five times than only sediments.

\section{References}

[1] B.E. Logan, B. Hamelers, R. Rozendal, U. Schroder, J. Keller, S. Freguia, P. Aelterman, W. Verstraete, and K. Rabaey, "Microbial fuel cells: Methodology and technology," Environmental Science \& Technology, Vol. 40, No. 17, pp. 5181-5192, 2006. doi: 10.1021/es0605016

[2] R. Nitisoravut, C.N.D. Thanh, and R. Regmi, "Microbial fuel cells: Advances in electrode modifications for improvement of system performance," International Journal of Green Energy, Vol. 14, No. 8, pp. 712-723, 2017. doi: 10.1080/15435075.2017.1326049

[3] D.P.B.T.B. Strik, H.V.M. Hamelers, J.F.H. Snel, and C.J.N. Buisman, "Green electricity production with living plants and bacteria in a fuel cell," International Journal of Energy Research, Vol. 32, No. 9, pp. 870-876, 2008. doi: 10.1002/er.1397

[4] R. Nitisoravut, and R. Regmi, "Plant microbial fuel cells: A promising biosystems engineering," Renewable and Sustainable Energy Reviews, Vol. 76, pp. 81-89, 2017. doi: 10.1016/j.rser.2017.03.064

[5] N. Kaku, N. Yonezawa, Y. Kodama, and K. Watanabe, "Plant/microbe cooperation for electricity generation in a rice paddy field," Applied Microbiology and Biotechnology, Vol. 79, pp. 43-49, 2008. doi: 10.1007/s00253-008-1410-9 
[6] M.A. Moqsud, J. Yoshitake, Q.S. Bushra, M. Hyodo, K. Omine, and D. Strik, "Compost in plant microbial fuel cell for bioelectricity generation," Waste Management, Vol. 36, pp. 6369, 2015. doi: 10.1016/j.wasman.2014.11.004.

[7] S.W. Hong, Y.S. Choi, T.H. Chung, J.H. Song, and H.S. Kim, "Assessment of sediment remediation potential using microbial fuel cell technology," International Journal of Social, Behavioral, Educational, Economic, Business, and Industrial Engineering, Vol. 3, No. 6, pp. 683-689, 2009.

[8] R. Regmi, and R. Nitisoravut, "Effect of configuration and growth stages on bioenergy harvest in the paddy type microbial fuel cell under greenhouse condition," Paper presented at International Conference on Green Energy and Applications (ICGEA), Singapore, 2017.

[9] Y. Goto, N. Yoshida, Y. Umeyama, T. Yamada, R. Tero, and A. Hiraishi, "Enhancement of electricity production by graphene oxide in soil microbial fuel cells and plant microbial fuel cells," Frontiers in Bioengineering and Biotechnology, Vol. 3, 2015. doi: 10.3389/fbioe.2015.00042

[10] S. Liu, H. Song, X. Li, and F. Yang, "Power generation enhancement by utilizing plant photosynthate in microbial fuel cell coupled constructed wetland system," International Journal of Photoenergy, Vol. 2013, 2013. doi: 10.1155/2013/172010

[11] I. Gajda, J. Greenman, C. Melhuish, I. Leropoulos, "Self-sustainable electricity production from algae grown in a microbial fuel cell system," Biomass and Bioenergy, Vol. 82, pp. 8793, 2015. doi: 10.1016/j.biombioe.2015.05.017

[12] R. Regmi, R. Nitisoravut, S. Charoenroongtavee, W. Yimkhaophong, and O. Phanthurat, "Earthen pot-plant microbial fuel cell powered by Vetiver for bioelectricity production and wastewater treatment," Clean-Soil, Air, Water, Vol. 46, No. 3, 2018. doi: 10.1002/clen.201700193

[13] S. Bocchi, and A. Malgioglio, "Azolla-Anabaena as a biofertilizer for rice paddy fields in the Po Valley, a temperate rice area in northern Italy," International Journal of Agronomy, Vol. 2010, 2010. doi: 10.1155/2010/152158

[14] C. Neinhuis, and W. Barthlott, "Characterization and distribution of water-repellent, selfcleaning plant surfaces,” Annals of Botany, Vol. 79, No. 6, pp. 667-677, 1997. doi: 10.1006/anbo.1997.0400 